\title{
POSITION OF ENTREPRENEURSHIP EDUCATION IN LITHUANIAN GENERAL EDUCATION CURRICULUM AND IN EDUCATIONAL PROCESS IN GENERAL EDUCATION SCHOOL
}

\author{
Romas Prakapas \\ Gintautė Žibènienė \\ Mykolas Romeris University, Lithuania
}

\begin{abstract}
Entrepreneurship, as one of today's most relevant competences, is widely discussed in the public space. We must admit that scientific discussions have not yet led to a unanimous definition of the phenomenon, although the studies themselves are quite abundant. On the other hand, considering the social reality as being subject to constant change, it is also important to analyse the documents which are directly related to change of content of the said education. Scientific problem can be set as follows: what entrepreneurship education is provided in today's general education school of Lithuania. Purpose - toreveal position of entrepreneurship education in Lithuanian general education curriculum and in educational process in general education school. It analysed the regulations on the Lithuanian general school curriculum content of the school year 2016-2017 in terms of the development of entrepreneurship: strategies, curricula, resources, etc. The analysis shows that in terms of modelling of curriculum formal education is aimed at training entrepreneurship following the principles of holistic approach, integrity and consistency. Lithuanian general curricula for general education are modelled in such a way that the learners integrally understand entrepreneurship, from different perspectives of subjects, as an integral competence.
\end{abstract}

Keywords: entrepreneurship education, general education curriculum, general education school.

\section{Introduction}

Entrepreneurship, as one of today's most relevant competences, is widely discussed in the public space. Various studies (Zaleskienė \& Žadeikaite, 2008; Jelagaite \& Vijeikis, 2012; Žibėnienė \& Virbalienè, 2014; Dudaitė et al., 2015, etc.), as well as rapid and constant change of the education phenomenon show the efforts of the scientists to understand the key components of the phenomenon of entrepreneurship, because study of legal environment highlights the significance of entrepreneurship competence for today's person. We must admit that scientific discussions have not yet led to a unanimous definition of the phenomenon, 
although the studies themselves are quite abundant. The latest World Economic Forum experts' report on the vision for future education (New Vision for Education, 2016) addresses the growing gap between the skills developed and those needed in real life. In the list of the $21^{\text {st }}$-century skills, the competence of entrepreneurshipis defined through its specific features: creativity, financial literacy, critical thinking, etc. In terms of today and the 5-year prospect, the only change seen is that in the weight of the individual components.

On the other hand, considering the social reality as being subject to constant change, it is also important to analyse the documents which are directly related to change of content of the said education. In the light of the frequent discussions in the public space regarding the lack of young people's entrepreneurship competence, closer analysis of preconditions and reasons of entrepreneurship education or non-education is necessary. Therefore, scientific problem can be set as follows: what entrepreneurship education is provided in today's general education school of Lithuania.

Subject - entrepreneurship education in general education school of Lithuania.

Purpose - toreveal position of entrepreneurship education in Lithuanian general education curriculum and in educational process in general education school.

Research methodology. The research was designed according to the principles of the case study research strategy (Yin, 2014). It analysed the regulations on the Lithuanian general school curriculum content of the school year 2016-2017 in terms of the development of entrepreneurship: strategies, curricula, resources, etc. The methods for research data collection included document analysis and meta-analysis, and the data were processed using the methods of content analysis, classification, comparison, and generalisation. The research was carried out in accordance with the main requirements for research ethics (Herrera, 2010).

\section{Entrepreneurship education in general education school in Lithuania}

Entrepreneurship and its development are addressed in the EU documents and reports (Entrepreneurship education policies, 2011; Entrepreneurship Education: Enabling Teachers as a Critical Success Factor, 2011; Entrepreneurship Education at School in Europe, 2012). The analysis of these documents shows the relevance of the entrepreurship competence to an individual, highlights the need to foster the development of entrepreneurship skills, and reveals the holistic concept of entrepreneurship. 
Foreign scientists carry out rather wide studies of the phenomenon of entrepreneurship by discussing the concept, separate components of the content, etc. However, notwithstanding the fact that foreign studies enrich scientific cognition, the particularity of national context still remains.

The strategic documents for Lithuanian education highlight specific skills and competences necessary for the young generation, the following being named as the key skills:

- continuous learning,

- critical thinking,

- problem solving,

- decision making,

- adhering to moral principles,

- undertaking and fulfilling obligations,

- taking responsibility for one's actions,

- establishing goals and priorities for life and activity and pursuing them,

- openness to new ideas and experiences,

- proactiveness and independence,

- $\quad$ activeness, etc.

In other words, the documents governing Lithuanian education highlight the main characteristics of entrepreneurship, which is emphasised in the EU strategic documents as one of the competences necessary for the 21-st century individual.

It is important to integrate entrepreneurship education into the process of education in general education schools. The action plan for entrepreneurship 2020 (Entrepreneurship 2020 action plan, 2014:5), states that,,education institutions should be encouraged to become more entrepreneurial in their wider approach, to ensure that they develop and live a culture of entrepreneurship and innovation through their missions, leadership, stakeholder engagement, curricula and learning outcomes".

The analysis of documents and research literature shows that the success of the process of entrepreneurship education depends on the conditions created at the general educationschool: teacher professional development, teaching/lerning methods, and tools and resources for entrepreneurship education. Since entreprneural education is integrated into different subjects, general curricula for general education have become one of the key elements.

According to the EU reports, one of the main challenges for the general education school is the applicaton of specific and efficient teaching/lerning methods in entrepreneurship education. The European Comission reports (Entrepreneurship education policies, 2011; Entrepreneurship Education: Enabling Teachers as a Critical Success Factor, 2011; Towards Greater Cooperation and Coherence in Entrepreneurship Education, 2010) distinguish the 
aspects of entrepreneurship education which need to be improved. One of the most important factors is the development of efficient learning methods in entrepreneurship education.

Sytemised surveys carried out in different countries where entrepreneurship education takes place show that the practice of Lithuanian schools is successful. However, the analysis of general education schools reveals that the issue of the applicationofteaching/lerning methods is also relevant to Lithuanian teachers. The most popular methods applied in work of teachers are work in small groups, problem solving and group project. Meetings with business people, preparation of business plan, school fair, workshop and particularly teaching company are much rarer. However, many teachers indicate other methods they use in their work: discussions, reflection, brainstorming, case study, role-playing game, i.e. the methods which can be used in daily work more easily compared to preparation of fairs, workshops, invitation of business people to school, etc. The majority of teachers apply various educational methods and forms not specifically for entrepreneurship education, but in education process in general (Dudaite et al., 2015).

Although scientific and methodoligal literature includes a number of attempts to distinguish the best and most appropriate teaching / learning methods for entrepreneurship education, the analysis reveals different priorities which emerge due to the differences in interpretation of the concept of entrepreneurship. Therefore, priorities may vary from an orientation towards writing a business plan to simply using active rather than passive teaching / learning methods. However, the suggestion by A. A. Gibb (1993) to apply the method of learning based on active experience, when students are encouraged to find and analyse problems in variuos areas and of different levels of difficulty, learn to deal with failures, and think independently, is still relevant. An assumption may be madethatteachers who work in the context of the paradigm of the shift from teaching towards active learning must understand that learning is individual and unique; it is constructive individual activity based on previous individual learning and on individual and unique experience. Learning is based on experience, skills, and every individual learner's specific learning strategies. There is no one universal teaching/learning method or strategy suitable to everyone; therefore, teachers should use various teaching/learning methods, tasks and experiences to encourage learners' active involvement in the learning process, and meet their individual needs. Teaching/learning methods in entrepreneurial education should be varied and facilitate achieving set aims, objectives and expected results; they should meet the learners' needs and match the methods of individual progress assessment as well as other components of teaching content.

Assessment of entrepreneurship education practice in general education school of Lithuania showed that quite wide choice of entrepreneurship education 
tools are available for general education schools. Most of them are textbooks which are basically prepared for the lessons of economics but can also be used for entrepreneurship training during other lessons and extra-curricular activities. Sets of methodological recommendations for teachers are intended to assist in integrating entrepreneurship into various subjects and extra-curricular activities (Dudaite et al., 2015). On the other hand, the need for and importance of the system for teacher qualification improvement in terms of entrepreneurship education is particularly high. Projects on teacher qualification improvement in terms of entrepreneurship education are rather scarce. Therefore, even though the projects on teacher qualification improvement are significant they do not bring considerable improvement to the situation of the entrepreneurship education because the projects are not implemented on a continuous, systematic and regular basis. So far there is no single institution in Lithuania which would organize the qualification improvement courses for teachers of entrepreneurship education and offer professional self-development opportunities, although legal documents define the need for such institution.

On the other hand, the problem of teacher professional development is not unique to Lithuanian general education teachers. A report commissioned by the European Comission (Entrepreneurship Education: Enabling Teachers as a Critical Success Factor, 2011) states that entrepreneurship education is included in strategic curricula in more and more European countries every year; yet little attention is given to the training and systematic professional development of entrepreneurship education teachers.

\section{Position of entrepreneurship education in Lithuanian general education curricula}

Formally, the key and most important national documents regulating general education curriculum in general education schools in Lithuania are general programmes. Separate documents define the main characteristics of organisation and implementation of education that are oriented towards separate stages of formal education: primary, basic and secondary. Historically, when Lithuania regained its independence, first draft curricula of separate stages were prepared, and subsequently, as a response to the challenges of the time, specific curricula were developed. In the general education schools of Lithuania, the curriculum is now modelled according to the latest versions of general curricula prepared pursuant to the Strategy for Developing, Evaluating, Renewing, and Implementing the Curriculum of General Education (2007) approved by the Order of the Minister of Education and Science of the Republic of Lithuania. Primary, basic and secondary education curricula define the general provisions, the main trend of education, principles, purpose, goals and tasks, competences to be 
Romas Prakapas, Gintaute Žibènienè. Position of Entrepreneurship

Education in Lithuanian General Education Curriculum and in Educational Process in General Education School

trained, values, curriculum and methods, curriculum inner consistency, integration potential, etc.

Table 1 Purpose of general curricula for general education in Lithuania

\begin{tabular}{|l|l|}
\hline $\begin{array}{c}\text { General curricula for primary and } \\
\text { basic education (2008) }\end{array}$ & \multicolumn{1}{|c|}{$\begin{array}{c}\text { General curricula for secondary education } \\
\text { (2011) }\end{array}$} \\
\hline $\begin{array}{l}\text { The general curricula define } \\
\text { educational content on national level. } \\
\text { Schools and teachers design } \\
\text { educational content on school and } \\
\text { class levels in accordance with the } \\
\text { general curricula and adapt it to the } \\
\text { needs of an individual class and } \\
\text { learner in order to enable students to } \\
\text { achieve their best possible results. }\end{array}$ & $\begin{array}{l}\text { Thent on the national education system level. They } \\
\text { national education system. Schools design } \\
\text { educational content on school level in accordance } \\
\text { with the general curricula so that it meets the needs } \\
\text { of particular student groups and individual students. } \\
\text { Teachers design educational content on class } \\
\text { (student group) and student level in compliance with } \\
\text { the general curricula and the school-level } \\
\text { educational content in order to enable students to } \\
\text { achieve their best possible results. }\end{array}$ \\
\hline
\end{tabular}

General curricula for both 2008 and 2011 are strongly oriented towards decentralization of curriculum development (adaptation of curriculum for students with different needs, etc.). In certain aspect, strengthening of autonomy of schools is observed, which allows a school to choose its own way of autonomy development. Hence, comparison of structure of different stages of education (primary, basic, and secondary) and general curricula for general education reveals that they are very similar, correspond to psychosocial, emotional, physical and intellectual development of learners, and retain consistency and continuity. Structural differences are observed only in some points of general curricula for general education: in primary and basic education more attention (compared to secondary education) is given to both horizontal and vertical integration of curriculum; entrepreneurship training, in a targeted manner (in a formal way), starts only after completion of primary education curriculum. The documents emphasize that in order to train and develop entrepreneurship competence of learners of different age and abilities the entrepreneurship training should be integrated into various subjects.

The concept of entrepreneurship in principle is not used in the general curricula for primary education. The situation is slightly different in terms of characteristics describing the phenomenon of entrepreneurship, such as initiative, creativity, perseverance, responsibility, logical and critical thinking. Most attributes of entrepreneurship education can be noticed in analysing general objectives of education and creation of educational environment, providing interdisciplinary relations, discussing the values to be fostered, etc. 
The analysis of international documents dealing with entrepreneurship allows for an assumption that the vision of an entrepreneureducatedin Lithuanian general education schools corresponds to the topicalities of entrepreneurship education addressed in international documents (Entrepreneurship Education at School in Europe, 2012; Entrepreneurship Education: A Guide for Educators,2013; Entrepreneurship Education: Enabling Teachers as a Critical Success Factor, 2011; New Vision for Education, 2016).

Table 2 Components of entrepreneurship competence in Lithuanian general curricula for general education

\begin{tabular}{|c|c|c|c|}
\hline \multirow{2}{*}{$\begin{array}{c}\text { Characteristics of } \\
\text { competence of } \\
\text { entrepreneurship }\end{array}$} & \multicolumn{3}{|c|}{ Lithuanian general curricula for general education } \\
\cline { 2 - 4 } & Primary education & Basic education & $\begin{array}{c}\text { Secondary } \\
\text { education }\end{array}$ \\
\hline readiness to take risk & developed indirectly & developed & developed \\
\hline business setting-up skills & not developed & developed & developed \\
\hline openness to innovation & developed indirectly & developed & developed \\
\hline
\end{tabular}

The separal components of entrepreneurship competence as perseverance, responsibility, planning skills, turning ideas into actions, critical thinking, creativity, logical thinking, innovative thinking, independence, self-regulation, tolerance are developed and directly expressed in all general curricula for general education. Lithuanian general curriculum of primary education and primary education curricula analysis revealed that some characteristics of competence of entrepreneurship (readiness to take risk, business setting-up skills, openness to innovation) not expressed or not developed or developed indirectly (see table 2).

As regards basic education, entrepreneurship is also integrated into different structural parts of general curricula (except Economic and Entrepreneurship education curricula - an independent subject which presents entrepreneurship in the narrow sense: ,the main aim of economic and entrepreneurship education at basic school is to pursue that students gain the basics of economics, purposefully develop entrepreneurship skills, form an economic mindset, and are able to adequately orientate and successfully operate in a constatntly changing economic environment" (Valstybės žinios, 2008). Similarly to general curricula for primary education, components of entrepreneurship competence expressed by different attributes are provided in the general part of general curricula for basic education by describing purposes, tasks, integration potential, educational environment, general provisions, values to be fostered, etc.

In terms of secondary education curriculum, unlike basic education curriculum, the subject covering entrepreneurship is not compulsory forstudents in any of classes. The subject of economics and entrepreneurship is a free elective responding to the educational needs of students and their individual choice of field 
of study. Hence, formally, in the curriculum of secondary education, just as in the curriculum of basic education, only one subject is dedicated to entrepreneurship training. However, closer analysis of the said curricula reveal analogous situation in terms of basic education curriculum: the aim is versatile personality development pursuant to the specific objectives of the education of general competences.

It should be noted that in addition to formal education, an increase in various initiatives related to entrepreneurship training has been lately observed in Lithuania. Various projects, programmes and instruments for the implementation of different programmes or training of competences have been prepared. Entrepreneurship education receives much attention not only from vocational schools and higher education institutions but various centres, public organizations are also established, closer cooperation with business people is carried out.

Students are offered simulation games and virtual classrooms. Adopting international experience, Vilnius City and County Business Emplyers' Confederation has attempted to implement the entrepreneurship education programme TOC for Education in ten general education schools in Lithuania. Besides others, the Lithuanian Junior Achievement programmeis probably the most widely-spread non-formal entrepreneurship training initiative in Lithuania (Dudaitè et al., 2015).

Aforesaid of non-formal education programmes are successfully harmonized with general education by integrating non-formal programmes or separate components thereof. Yet, such integration is mostly performed in the programmes of basic and secondary education level, e.g. by teaching economics and entrepreneurship as a compulsory subject at the basic education stage, or as free elective at the secondary education stage.

In summary, it should be mentioned that most non-formal educational programmes and projects orientated towards the development of the competence of entrepreneurship are related to the understanding and intrepretation of entrepreneurship in its narrow sense, i.e. in the sense of setting up a business.

\section{Conclusions}

The vision of an entrepreneurship educated in Lithuanian general education schools corresponds to the topicalities addressed in international documents.

Teacher professional development, teaching/lerning methods, and tools and resources for entrepreneurship education are important forthe success of the process of entrepreneurship education at general education school. Since entreprneurship education is integrated into different subjects, general curricula for general education have become one of the key elements. 
The variety of tools and resources for entrepreneurship education available in general education schools is wide; however, selection and application of efficient teaching/learning methods and teacher professional development areamong the issues in Lithuania as well as in most EU member states.

The analysis of general curricula for general education in Lithuania shows that in terms of modelling of curriculum formal education is aimed at training entrepreneurship following the principles of holistic approach, integrity and consistency. Lithuanian general curricula for general education are modelled in such a way that the learners integrally understand entrepreneurship, from different perspectives of subjects, as an integral competence. In turn, considering the maturity of the learners, the targeted training subjects (e.g. economics and entrepreneurship, etc.) at different stages of education are aimed at development of targeted special competences which, in an inductive manner, combine abilities and competences acquired by means of interdisciplinary relations. The research showed that in Lithuania only formal education focuses on the entrepreneurship training, while non-formal entrepreneurship education lacks consistency and continuity. Part of non-formal education programmes on entrepreneurship are episodic and fragmentary.

\section{References}

Bendrojo lavinimo ugdymo turinio formavimo, vertinimo, atnaujinimo ir diegimo strategija (2007). Valstybès žinios, 63 (2440).

Dudaitè, J., Januškevičiūtè, A., Prakapas, R., Virbalienė, R., \& Žibènienė, G. (2015). Verslumo ugdymas Lietuvos bendrojo ugdymo mokyklose: mokslo studija. Vilnius: Mykolo Romerio universitetas.

Entrepreneurship 2020 action plan (2014). Communication from the Commissionto the European Parliament, the council, the European Economic and Social Committee and the Committee of the Regions. Downloaded fromhttp://eur-lex. europa.eu/LexUriServ/LexUri Serv.do?uri=COM:2012:0795:FIN:EN:PDF [žiūrèta 2014-09-16].

Entrepreneurship education policies. (2011). Investment, Enterprise andDevelopment Commission Multi-year Expert Meeting on Enterprise Development Policies and Capacitybuilding in Science, Technology and Innovation (STI). Third session Geneva, 19-21 January 2011. Downloaded from http://unctad.org/en/Docs/ciimem1crp2_en.pdf

Entrepreneurship Education: A Guide for Educators. (2013). Bruxelles: Enterpriseand Industry.

Entrepreneurship Education: Enabling Teachers as a Critical Success Factor. (2011).A report on Teacher Education and Training to prepare teachers for the challenge of entrepreneurchip education. Downloaded from http://ec.europa.eu/enterprise/policies/ sme/promotingentrepreneurship/files/education/teacher_education_for_entrepreneurship_ final_report_en.pdf

Entrepreneurship Education at School in Europe, 2012. [interaktyvus] http://eacea.ec. europa.eu/education/eurydice/documents/thematic_re-ports/135EN.pdf 
Romas Prakapas, Gintaute Žibenienè. Position of Entrepreneurship

Education in Lithuanian General Education Curriculum and in Educational Process in

General Education School

Gibb, A. A. (1993). The enterprise culture and education, understanding enterprise education and its links with small business entrepreneurships and educational goals. International small business management journal, 11 (3), p. 11-34.

Herrera, C. (2010). Ethics in the Research Process. In Neil J. Salkind (Ed.), Encyclopedia of Research Design. (pp. 426-431). Thousand Oaks, CA: SAGE Publications, Inc.

Jelagaite, A., \& Vijeikis, J. (2012). Verslumo ugdymas Lietuvos švietimo sistemoje. Management Theory \& Studies for Rural Business \& Infrastructure Development, 32 (3), 40-49.

New Vision for Education: Fostering Social and Emotional Learning Through Technology (2016). http://www3.weforum.org/docs/WEF_New_Vision_for_Education.pdf

Pradinio ir pagrindinio ugdymo bendrosios programos (2008). Valstybès žinios, 99 (3848).

Towards Greater Cooperation and Coherence in Entrepreneurship Education. (2010).Report and Evaluation of the Pilot Action High Level Reflection Panels on Enrepreneurship Education initiated by DG Enterprise and Industry and DG Education and Culture. Downloaded from http://old.jae.org/Download/ entr_education_panel_en.pdf

Vidurinio ugdymo bendrosios programos (2011). Valstybès žinios, 26 (1283).

Yin, R. K. (2014). Case study research: design and methods. Los Angeless (Calif.): Sage Publications.

Zaleskienè, I., \& Žadeikaite, L. (2008). Mokytojų požiūris ị verslumo ugdymo prielaidas. Pedagogika, 89, 99-106.

Žibènienè, G., \& Virbalienè, R. (2014). Shared understanding on the concept of Entrepreneurship education by teachers and Businessmen: the concept of entrepreneurship Education in Lithuanian schools shared by Teachers and businessmen. Society, Integration, Education, 1, 505-518. 